\title{
Digital Information Resources for Disaster Management of Libraries and Information Centres
}

\author{
Bidhan Chandra Biswas ${ }^{1}$ \\ and \\ Sabuj Kumar Choudhuri ${ }^{2}$
}

\begin{abstract}
A library may procure contents in various sources and forms to serve their clients, particularly in the higher education and research institutes in the developed world to satisfy their urge for vital contents that inspire indigenous research. Libraries and information centres must take adequate measures to save their collection from natural or man-made hazards. To have a strong disaster management commitment for libraries and information centres, the role of digital information is most important. This paper begins with an understanding of disaster the meaning, types and its groups- and then seeks to identify parameters to design and develop a successful disaster management plan, cited examples with images, provided various sources for digital information to mitigate it. For heralding better tomorrow, a concerted effort is needed in this regard.
\end{abstract}

Keywords: Disaster, Disaster management, Disaster management in libraries and information centres

\section{What is Disaster?}

A disaster is the tragedy of a natural or human-made hazard (a hazard is a situation which poses a level of threat to life, health, property, or environment) that negatively affects society or environment. The Center for Research on the Epidemiology of Disasters (CRED) in Brussels, Belgium, uses the following definition. "A disaster is a situation or event which overwhelms local capacity, necessitating a request to a national or international level for external assistance."1

In the Australian Emergency Management Glossary a disaster is defined as: "A serious disruption to community life which threatens or causes death or injury in that community and/or damage to property which is beyond the day-to-day capacity of the prescribed statutory

${ }^{1}$ Department of Library \& Information Science, University of Kalyani, Nadia, West Bengal, India. E-mail: bidhan_kly@yahoo.com

${ }^{2}$ Librarian, Basanti Devi College, Kolkata, West Bengal, India. E-mail: sabooj_c@yahoo.co.in 
authorities and which requires special mobilisation and organisation of resources other than those normally available to those authorities".

Generally, disaster has the following effects in the concerned areas:

1. It completely disrupts the normal day to day life

2. It negatively influences the emergency systems

3. Normal needs and processes like food, shelter, health, etc. are affected and deteriorate depending on the intensity and severity of the disaster.

Thus, a disaster may have the following main features:-

- Unpredictability

- Unfamiliarity

- Speed

- Urgency

- Uncertainty

- Threat

Thus, in simple terms we can define disaster as a hazard causing heavy loss to life, property and livelihood. e.g. a cyclone killing 10,000 lives and a crop loss of one crore can be termed as disaster. In contemporary academia, disasters are seen as the consequence of inappropriately managed risk. These risks are the product of hazards and vulnerability. Hazards that strike in areas with low vulnerability are not considered a disaster, as is the case in uninhabited regions.

\section{Objectives of the Study}

The disaster and the protection, preservation of the human civilization in the library is itself a great challenge. To address the problem, the role of information through various digital sources is the key point for the present study. A well informed and well designed disaster management plan can save the library from these catastrophic events.

\section{Types of Disaster}

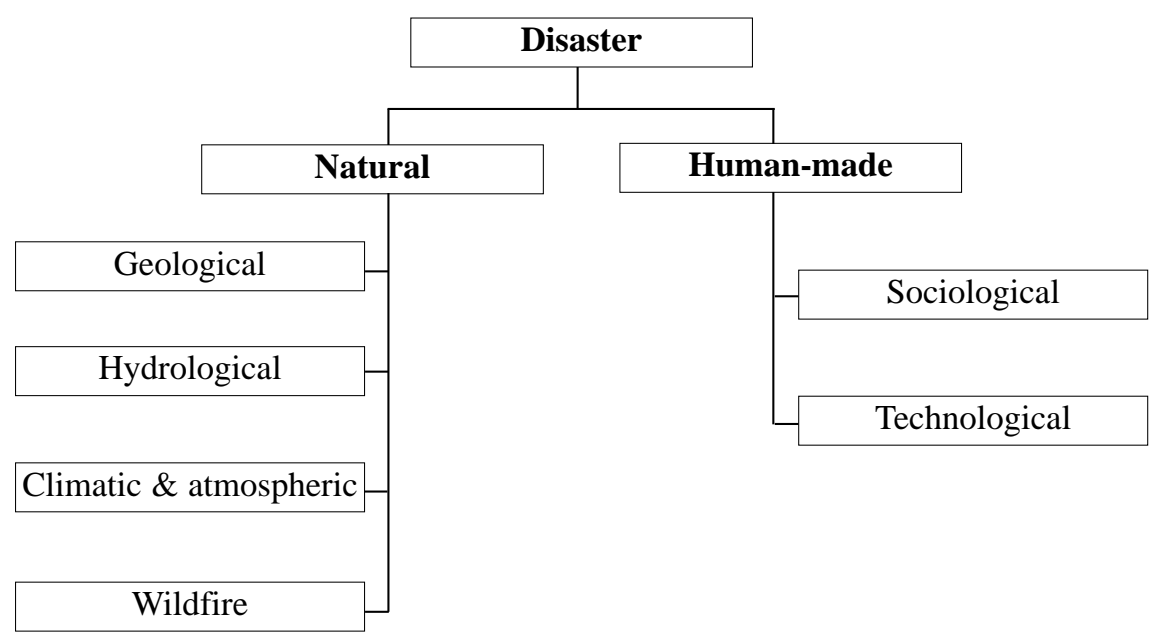




\section{Bangladesh Journal of Library and Information Science}

\section{Natural Disaster}

A natural disaster is a consequence when a natural hazard (e.g., volcanic eruption or earthquake) affects humans. Human vulnerability, caused by the lack of appropriate emergency management, leads to financial, environmental, or human impact.

\section{Human-made Disaster}

Disasters caused by human action, negligence, error, or involving the failure of a system are called man-made disasters. Man-made disasters are in turn categorized as technological or sociological. Technological disasters are the results of failure of technology, such as engineering failures, transport disasters, or environmental disasters. Sociological disasters have a strong human motive, such as criminal acts, stampedes, riots and war.

\section{Disaster and India}

India has been traditionally vulnerable to natural disasters on account of its unique geoclimatic conditions. Floods, droughts, cyclones, earthquakes and landslides have been recurrent phenomena. About $60 \%$ of the landmass is prone to earthquakes of various intensities; over 40 million hectares is prone to floods; about $8 \%$ of the total area is prone to cyclones and $68 \%$ of the area is susceptible to drought. The loss in terms of private, community and public assets has been astronomical.

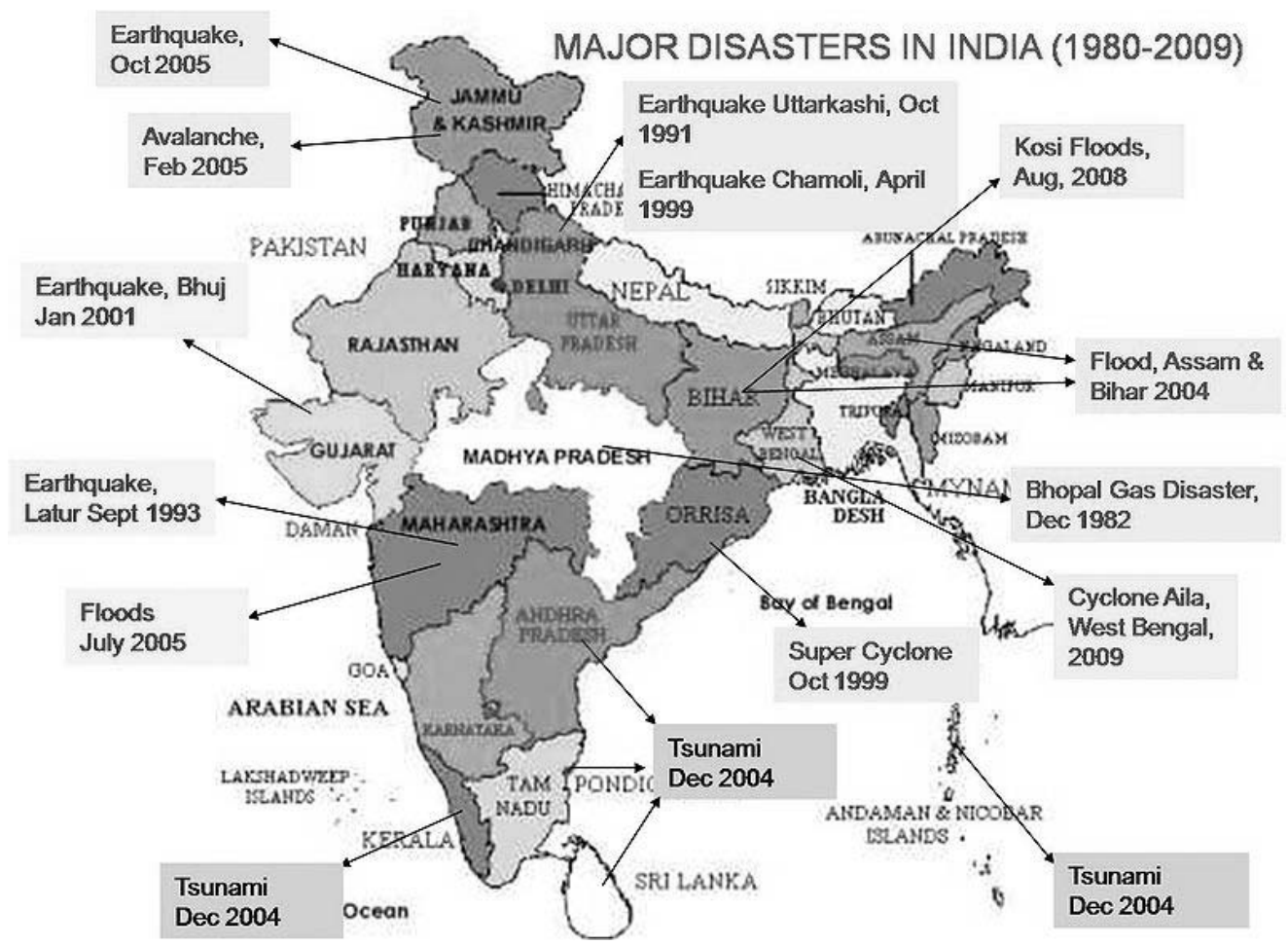

Fig.1 Major Disasters in India in the last 20 Years (1980-2009) 


\section{Human-made Disaster and the Library}

One million books, 10 million documents, and 14,000 archaeological artifacts have been lost in the U.S.-led invasion and subsequent occupation of Iraq - the biggest cultural disaster since the descendants of Genghis Khan destroyed Baghdad in $1258 .^{3}$

The International Committee of the Blue Shield declared on March 7, 2003, that "access to authentic cultural heritage is a basic human right" and that "Iraq is universally recognized to be especially rich in cultural heritage ... the loss of parts of that heritage would certainly represent a loss to all the peoples of the world." It called upon all nations with the ability to do so to draw up detailed plans to protect Iraqi cultural infrastructure and to assess and repair any damage done to it. Under the auspices of the Middle East Library Association, Jeff Spurr of Harvard University's Fine Arts Library has authored the most recent report on the condition of Iraqi academic libraries since the American invasion. Spurr reports that the "entire collection of 175,00 books sand manuscripts at the library of the University of Baghdad's College of Arts was reduced to ashes."

\section{Natural Disaster and the Library}

Earthquake, flood, cyclones, tornadoes, hurricanes and other natural disasters do cause immense and irreparable damage to the libraries. A public library run by Mukti (An NGO) in Nagendrapur in South 24 Parganas (near the Sunderbans) that serves the remote villages has been fully damaged in recent Aila.

\section{Disaster Management Plan for Libraries or Information Centre}

\section{Identifying Risks}

A prudent first step is to list geographic and climatic hazards and other risks that could jeopardize the building and collections. These might include the institution's susceptibility to natural as well as human made disaster.

\section{Decreasing Risks}

The disaster planner should devise a program with concrete goals, identifiable resources, and a schedule of activities for eliminating as many risks as possible.

\section{A Cooperative Plan}

Disaster planning should not take place in a vacuum. To work effectively, it must be integrated into the routine operating procedures of the institution.

\section{Identifying Resources}

Identify sources of assistance in a disaster. Determine the supplies you will need for disaster response and salvage efforts for your specific collections.

\section{Setting Priorities}

The first priority in any disaster is human safety. Saving collections is never worth endangering the lives of staff or patrons. 


\section{Bangladesh Journal of Library and Information Science}

\section{Key Digital Information Sources}

These Key information sources that address and respond to natural disasters provide links to valuable situation reports, media alerts and interactive mapping systems giving up to date information. It lists organizations and databases specializing in the complex events of a natural disaster.

\section{Important Databases \& Information Systems}

\section{Sahana}

http://www.sahana.lk/

Sahana is an integrated set of web-based disaster management applications that provide solutions to large-scale humanitarian problems in the aftermath of a disaster. It is open-access and freely downloadable from this site.

The main applications built into Sahana and problems they address so far are as follows:

- missing person registry

- organisation registry

- request management system

- camp registry

- volunteer management

- inventory management

- situation awareness

\section{SAHANA}

Sahana is a Free and Open Source Disaster Management system. It is a web based collab pration tool that adcresses the

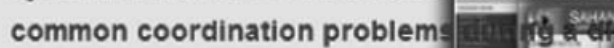
missing people, managing aid, society (NGOS) and the victims them

- Sahana Overview

- Screenshots

- Download and Install Sahana

Sahana Finalist in Sourceforge 2009 Community Choice Awards
- Reporta Bug

- Download

- Need Help?

- Project Overvis

- Screenshot:

- Demo

- Documentatio

- Installation

- Join Us \& Con

- Mailing Lists

- IRC Chat

- Report \& Fix

- Donate

r....... 


\section{Relief Web}

http://www.reliefweb.int

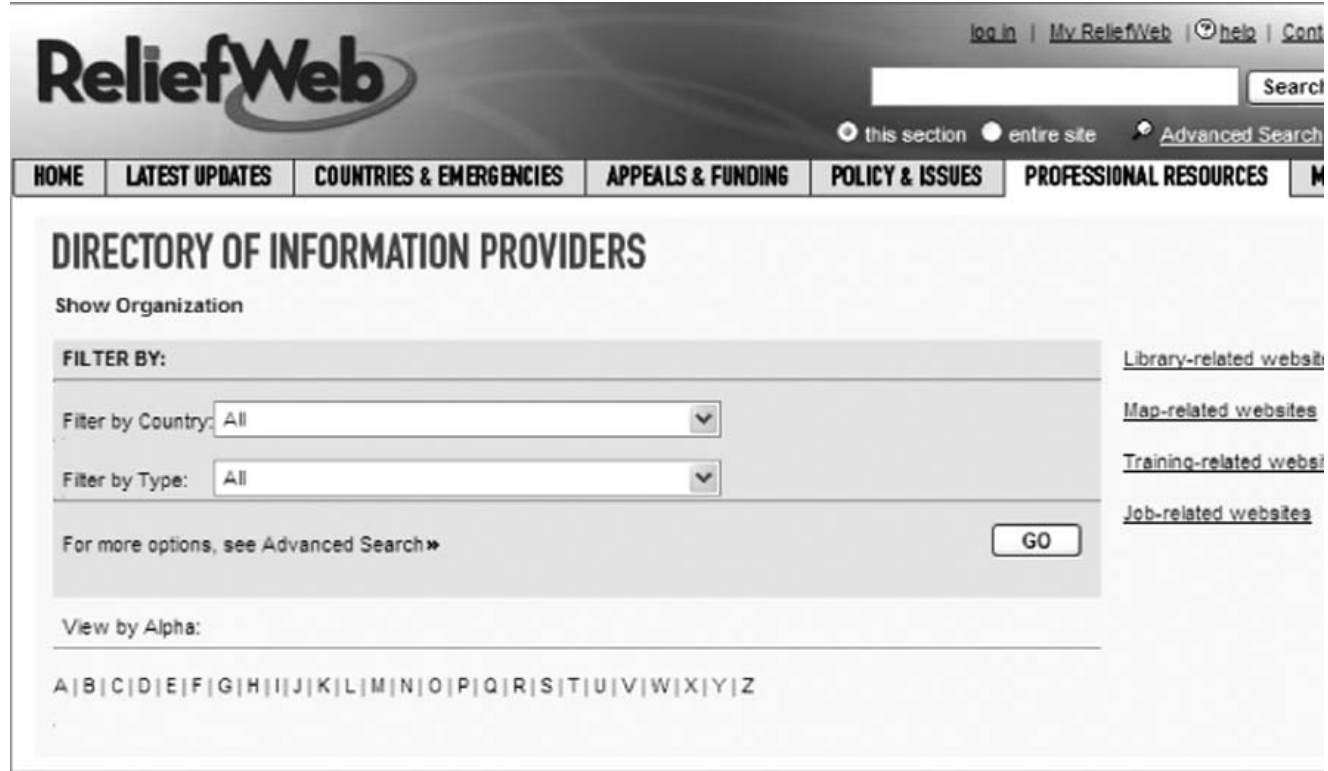

International Recovery Platform

http://irp.onlinesolutionsltd.net

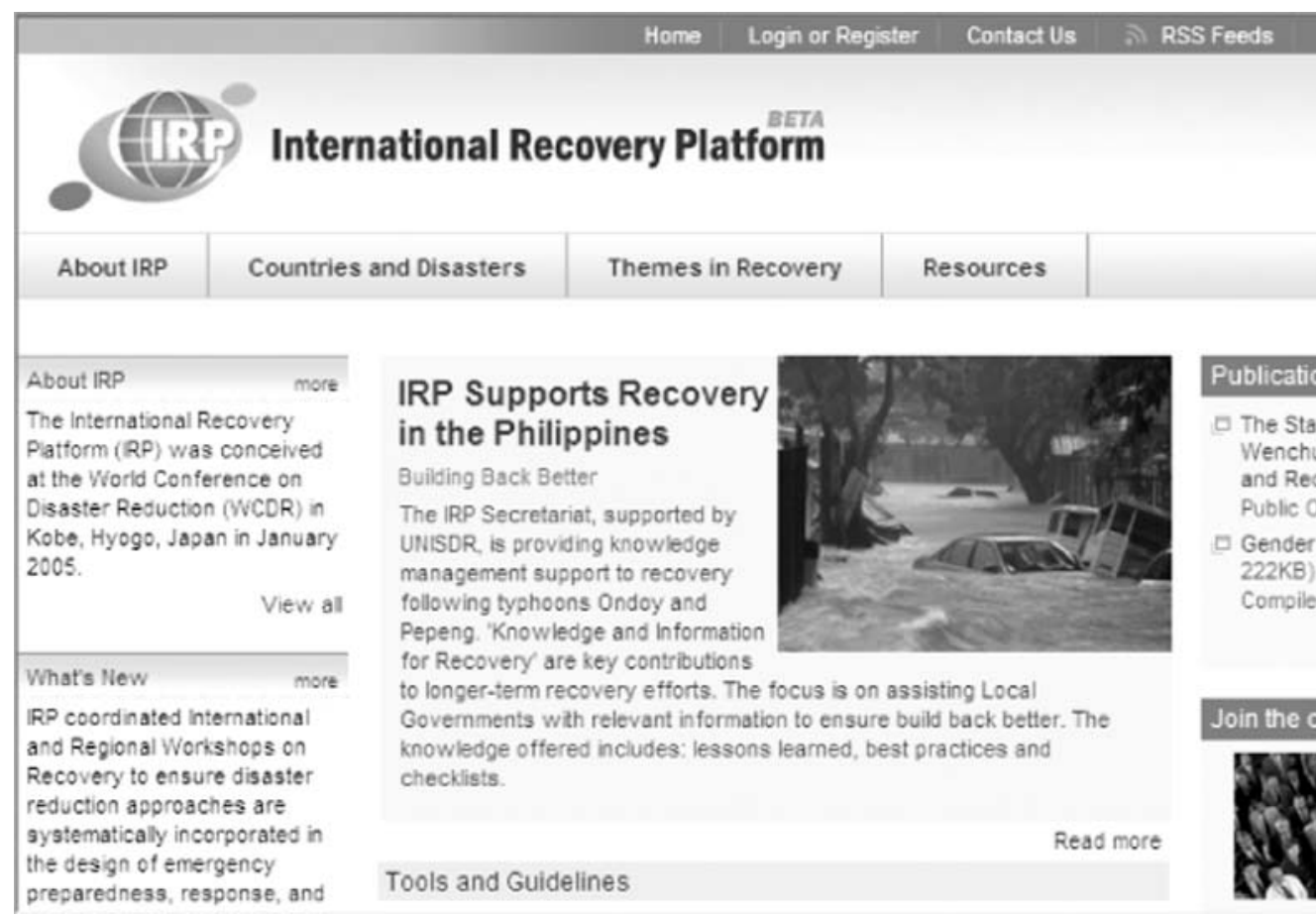




\section{Bangladesh Journal of Library and Information Science}

\section{Asian Disaster Reduction Centre}

http://www.adrc.asia

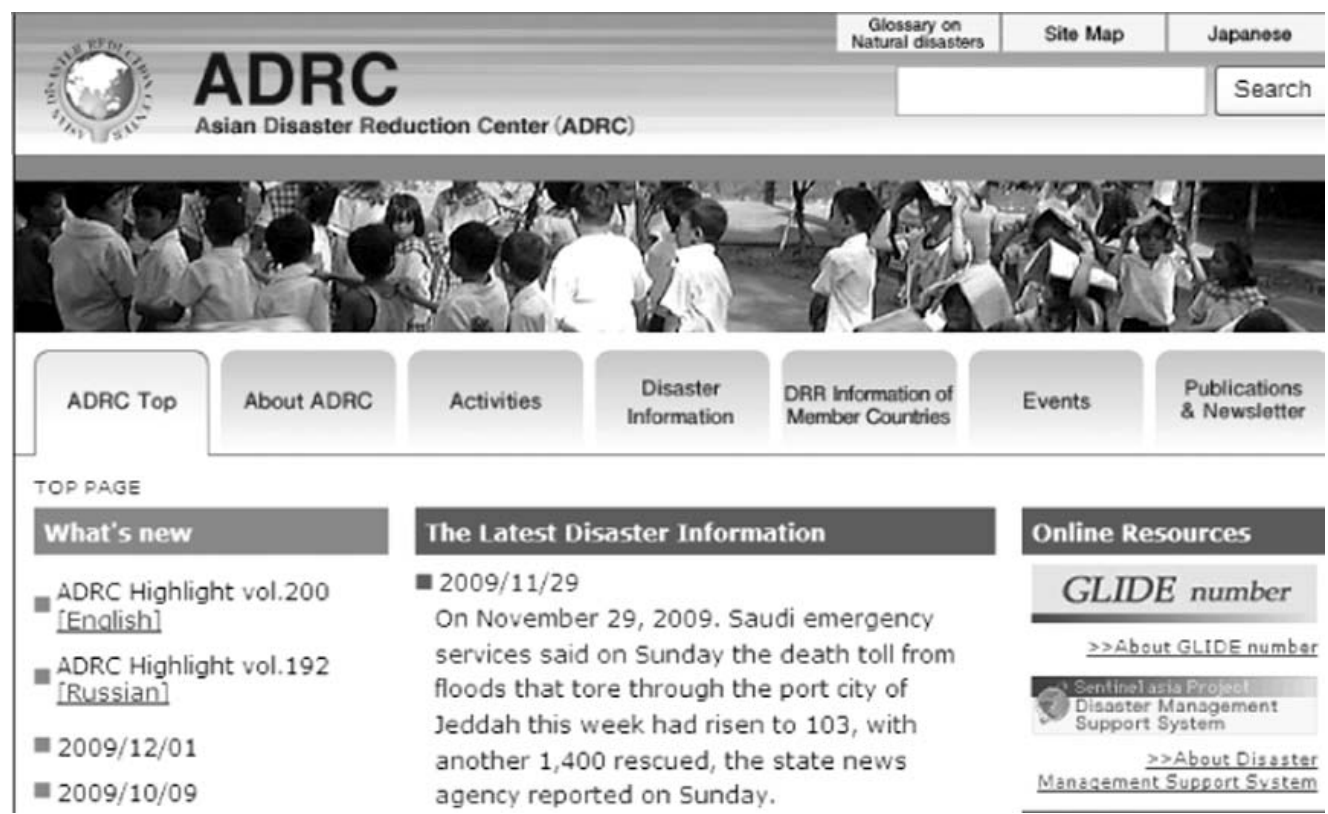

\section{National Sources}

National Disaster Management Authority

http://ndma.gov.in/ndma/index.htm

Ministry of Home Affairs

http://mha.nic.in/

Disaster Management Dept, Bihar Government

http://disastermgmt.bih.nic.in/

OSDMA

http://www.osdma.org/

GSDMA

http://www.gsdma.org/

India Meteorological Department

http://www.imd.ernet.in/

National Disaster Management, Govt. of India

http://www.ndmindia.nic.in/

National Centre for medium Range Weather Forecast

http://www.ncmrwf.gov.in/

Water Resource Department

http://www.orissawater.com/

Asian Ministerial Conference on Disaster Risk Reduction

http://www.amcdrrindia.com/ 
International Sources

Alerting Humanitarians to Emergencies

http://www.alertnet.org/

Centre for Disease Control and Prevention

http://www.cdc.gov/nceh/programs/emergenc/prevent/prev_em.htm

Disaster \& GIS related Information

http://www.esri.com/hazards

Disaster related News Service

http://www.disasternews.net/

Dundee Satellite Recieving Station

http://www.sat.dundee.ac.uk/

Earthquake related News from World news Service

http://www.earthquakenews.com/

Earthquake Related Information

http://www.eqnet.org/

Federal Emergency Management Agency

http://www.fema.gov/

Information about Emergency Planning \& Response

http://www.emergency-management.net/

Information about Tropical Cyclones

http://www.hurricanealley.net/

International Association of Emergency Managers

http://www.iaem.com/

International Federation of Red Cross

http://www.ifrc.org/

National Institute of Urban Search \& Rescue

http://www.niusr.org/

National Memorial Institute for Prevention of Terrorism

http://www.mipt.org/

Red Cross

http://www.redcross.org/

The National Emergency Management Association, US

http://www.nemaweb.org/

United Nations Development Programme

http://www.undp.org/

USGS Database

http://usg-georef.cos.com/

US Geological Survey

http://www.usgs.gov/

US Navy

http://www.npmoc.navy.mil/

Weather Safety Tips

http://www.w3.weather.com/safeside 


\section{Bangladesh Journal of Library and Information Science}

\section{Academic and Research Institutions}

Active Learning Network for Accountability and Performance in Humanitarian Action http://www.alnap.org/publications/publications.htm

Centre for Research on the Epidemiology of Disasters

http://www.cred.be/

Centre for Women’s Global Leadership Rutgers, State University of New Jersey

http://www.cwgl.rutgers.edu

Centro Regional de Información sobre Desastres

http://www.crid.or.cr/crid/ing_index.shtml

Stockholm International Peace Research Institute

http://first.sipri.org/

United States Institute of Peace

http://www.usip.org/library/

Universidad Carlos III de Madrid

http://www.uc3m.es/

University of Minnessota

http://www1.umn.edu/humanrts/

Yale University - The Diana Project

http://www.yale.edu/lawweb/avalon/diana/

\section{Governments and Intergovernmental Organisations}

British Library

http://www.bl.uk/

National Library of Canada

http://www.nlc-bnc.ca/

National Libray of Australia

http://www.nla.gov.au/

Russian State Library

http://www.rsl.ru/

\section{Non-Governmental Organizations}

European Public Law Center

http://www.eplc.gr/library/library.php

InterAction

http://www.interaction.org/library/index.php?mode=search

Library of Congress

http://www.loc.gov/

Women Waging Peace

http://www.huntalternatives.org/pages/82_women_waging_peace_network.cfm

\section{Other}

Georgia: Directory of Humanitarian and Development Organizations http://www.reliefweb.int/library/documents/2001/ocha_geo_16mar.PDF 
UN Agencies and International Organizations

Asian Disaster Reduction Center

http://www.adrc.or.jp/

UN High Commissioner for Refugees

http://www.unhcr.org/static/research/library.html

\section{For a Better Tomorrow}

Disaster planning is becoming an essential component of the overall management plan for a library and information centres. The importance of an effective disaster plan is regularly demonstrated in institutions which are strongly committed to their plans. There is ample evidence to indicate that to be effective, a plan must be incorporated into the day-to-day management of an institution. A well thought out and presented plan is useless if it exists solely as a document on a shelf.

Disaster planning is essential for any institution to provide the best possible protection for its collections. Disaster can strike at any time — on a small or a large scale — but if an institution is prepared with right information and the plan accordingly, the damage may be decreased or avoided. A disaster plan must be considered a living document. Its risk-assessment checklist must be periodically reviewed, its lists must be updated, and its collection priorities revised as needed. Always one thing should remember that without right information from the right sources no disaster plan can be successful. An effective disaster plan with strong information network and information system will do its best to insure that historical collections in our cultural institutions are safeguarded for the future.

\section{References}

1. Center for Research on the Epidemiology of Disasters (2009) [Online] Available from: http://www.md.ucl.ac.be/entites/esp/epid/misson/intro_uk.htm [Accessed $16^{\text {th }}$ Dec. 2009]

2. Australian Emergency Management Glossary (2009) [Online] Available from: http://www.ema.gov.au/www/ema/rwpattach.nsf/VAP/(A96D9A49EA98CFE780B96F6E E5A027F4) Glossary.doc/\%24file/Glossary.doc [Accessed $16^{\text {th }}$ December 2009]

3. Harding International Social Work (2007) Man-made disaster and development: The case of Iraq (50).pp 295-306

4. International Committee of the Fourth International (ICFI) (2009) [Online] Available from: http://www.wsws.org/articles/2005/sep2005/libs-s17.shtml [Accessed $16^{\text {th }}$ Dec. 2009]

5. Sahana (2009).[Online] Available from: http://www.sahana.lk/ [Accessed $14^{\text {th }}$ Dec. 2009]

6. Reliefweb (2009).[Online]Available from: http://www.reliefweb.int/ [Accessed $14^{\text {th }}$ December 2009].

7. International Recovery Platform (2009).[Online] Available from: http://irp. onlinesolutionsltd. net/ [Accessed $14^{\text {th }}$ December 2009].

8. Asian Disaster Reduction Centre (2009).[Online] Available from: http://www.adrc.asia [Accessed 14 ${ }^{\text {th }}$ December 2009].

9. National Disaster Management Authority (2009). [Online] Available from: http://ndma.gov.in/ndma/index.htm [Accessed $14^{\text {th }}$ December 2009]. 